\title{
SOME INSIGHTS THAT ORALITY-LITERACY STUDIES CAN OFEER LANGUAGE TEACHERS
}

\section{Hildegard van Zweel}

Department of Afrikaans

University of Durban-Westville

\section{Introduction}

The aim of this paper is to determine whether oralityliteracy studies can offer language teachers any insights into teaching students from oral backgrounds. In order to do so, I compare two approaches to literacy. They are the 'autonomous' model of Walter J. Ong and the 'ideological" model of Brain $V$. Street. The relevance of insights gleared from a comparison of these two models will be discussed in 6 below.

The terms "autonomous" and "ideological' that are used to describe models of literacy, are taken from street (1984:1ff). In Literacy in theory and practice, he examines claims made about the nature of literacy and related claims about language and society. And argues that, on the basis of these claims, a distinction must be drawn between the 'autonomous' model of literacy and the 'ideological' model of literacy. 
The two models can briefly be characterised as follows. The 'autonomous' model is based on the assumptions: (a) that literacy is a neutral technical skill, and (b) that literacy development takes place in a single direction that is associated with social and cognitive consequences (street $1984: 1 \mathrm{ff}$ ).

Street (1984:2) challenges these assumptions and suggests the 'ideological" model as an alternative model of literacy. Within the "ideological" model, literacy is viewed as a social practice which is culturally and ideologically embedded in the social institutions in which it is practiced. Its meaning is constructed by its participants and by particular social contexts.

I shall briefly discuss the assumptions about literacy which street claims are made within the 'autonomous' model.

\subsection{A 'great divide'}

Street (1984:5) claims that proponents of the "autonomous" model of literacy, such as Jack Goody, assume a "great divide' between 'literate' and 'non-literate'. According to street (1984:5), Goody

would explicitly replace the theory of a 'great divide' between 'primitive' and 'modern' culture. which had been employed in earlier anthropological theory and which is now discredited, with 
the distinction between "literate" and 'nonliterate".

street (1984:5) shows how this assumption of a 'great divide' between 'literate' and 'non-literate' is used by Goody as justification for further assumptions about the social and cognitive consequences of literacy. Goody regards literacy as 'closely connected to'. 'fostering', or even 'enforcing'

the development of 'logic', the distinction of myth from history, the elaboration of bureaucracy, the shift from "little communities" to complex cultures, the emergence of scientific thought and institutions, and even the growth of democratic political processes (street 1984:5).

3.2 Literacy development takes place in a single direction

Another assumption, according to street $(1984: 2)$, is that literacy development takes place in a single direction. This development is associated with 'progess'. 'civilisation', individual liberty and social mobility. The consequences of this development can be seen in terms of economic 'take off' and cognitive skills. It is specifically the assumptions made about the cognitive consequences of literacy that are of relevance to language teachers that will be discussed in this paper.

\subsection{Literacy as a neutral, technical skill}

The assumption that literacy has the above-mentioned social and cognitive consequences, is based on the assumption that literacy is a neutral technology which is the same for all 
people in all societies and that it can be detached from specific social contexts (street 1984:1). Claims about the neutrality of literacy are related to claims about the rational, detached, abstract, and context-free nature of written language (street 1984:2).1.

Street (1984:4,7) also criticises Olson's claims about 'autonomous' text and the neutrality of sentence meaning. saying he has counter-evidence for these claims. Street. cites the anthropological work done by Lienhardt (1980) on the underlying similarites between concepts used to represent 'self' by a sudanese tribe and that used by westerners.

3.4 Cognitive changes associated with literacy

Assuming the neutral and technical nature of literacy, many writers claim that literacy facilitates "...'abstract context-free thought', 'rationality', 'critical thought", 'detachment'...logical processes..." (street 1984:2). As we have seen above, Goody regards literacy as 'closely connected to'. 'fostering", or even "enforcing" the development of logic and the emergence of scientifc thought and institutions. I shall discuss the assumptions that logical and abstract thought and scientific thought are some of the cognitive consequences of literacy and street's criticism of these assumptions.

\subsubsection{Logical and abstract abilities}

Writers like Hildyard and olson "..have explicitly addressed themselves to questions of literacy and its cognitive consequences" (street 1984:19). They claim that the logical functions of language are significantly affected 
by literacy (street 1984:2).2 Hildyard and Olson base their claim on Greenfield's cross-cultural research into cognitive differences between schooled and unschooled wolof childen. Greenfield (1972:169) infers that persons from an oral language learn "...concrete activities and not abstract generalisations..." and avoid "...the classificatory and analytic isolating functions which words have in western culture" (street 1984:21). Greenfield (1972:174), furthermore, makes claims about gramatical form revealing "inferior cognitive facility" (street 1984:23). She tested unschooled wolof children's concept formation abilities by examining their grammatical structures. They were asked to name an attribute that a group of objects shared. If they simply said "red", instead of "they are red" their answer was judged unsatisfactory and indicative of inferior cognitive facility.

Street (1984:24) criticises the assmumption that literacy brings about logical and abstract thought, arguing that what has been taken to be lack of logical processes amongst 'primitive' people was often "...misunderstanding of the meaning of what was being said and done..." on the part of 11-informed European commemtators. Citing Labov, he (1984:26) argues that

representations of cognitive 'deprivation' were founded upon misunderstanding of the real meanings of such people's statements and actions, and upon ethnocentric assumptions about the ways in which logic can be recognised.

Regarding Greenfield's claim, that certain gramatical forms reveal inferior cognitive facility, street (1984:26) cites Labov's studies of negro youths in New York's ghetto: 
Eorms of speech which had been labelled 'ungrammatical', and taken as evidence of cognitive deprivation, are shown by Labov to be simply forms of dialect with no fundamental. consequences for cognitive performance. Leaving out the copula (to be), using double negatives, interchanging subjective and objective pronouns (he and him) can all be shown to be rule governed and consistent dialect practices, not evidence for an inability to express logical relations as Greenfield and some of the writers she cites had claimed (1972, p.173).

Street (1984:26) further refutes Greenfield's claim by pointing out that Labov and other linguists

recognise that such "nonstandard dialects are
highly structured systems" and that "the adult or
child who uses these rules must have formed at
some level of psychological organisation clear
concepts of "tense marker", "verb phrase", "rule
ordering". "sentence embedding", "pronoun" and
many other grammatical categories which are an
essential part of any logical system" (ibid.
p.45).

Street (1984:26-27) criticises so-called tests for logic. saying that these tests are unreliable in method and conception. And, furthermore, points out Labov's assertion that what is tested, is often the social conventions of a dominant class, rather than universal logic. According to Labov, the convention most often mistaken for logic is explicitness which is not the same thing as logic. ${ }^{3}$ 


\subsubsection{Scientific thought}

Goody's claim that literacy fostexs or enforces the emergence scientific thought is also criticised by street. He (1984:25) argues that Evans-Pritchard has pointed out that

the divisions between scientific and nonscientific thinking as such, if they can indeed be reliable established, do not necessarily correlate with different social groups.

Evans-Pritchard has also pointed out that members of 'primitive' societies did engage in scientific practices such as empirical hypothesis-testing.

street (1984:26) concludes that

anthropological evidence...suggests that there is scientific and non-scientific thought in all societies and within all individuals. observers have simply failed to remark the scientific nature of much of the thinking of so-called 'primitive' peoples and have perhaps overstated the 'scientific' nature of thinking in their own societies.

\subsection{Ong "s "autonomous" model}

I argue that given ong's (1982) view of literacy as a neutral technology which is accompanied by specific cognitive consequences, it would be justified to label his model of literacy an 'autonomous' model. Another reason for placing Ong's model within the 'autonomous" camp, would be his support of Goody's ideas. street (1984:5) regards coody's views as representative of the 'autonomous' model 
and as influential with regard to other anthropologists. Ong (1982:6) says about Goody's (1968, 1977) work that it "...provide(s) invaluable descriptions and analyses of changes in mental and social structures incident to the use of writing".

Ong's (1982:78) main claim is that "writing has transformed human consciousness". He (1982:78ff) elaborates this by making the following very specific claims about the cognitive consequences of 1 iteracy.

First, he claims that writing establishes context-free language or autonomous discourse. This he (1982:78) characterises as "discourse which cannot be directly questioned or contested as oral speech can be because written discourse has been detached from its author".

Second, ong (1982:81ff) claims that writing is a technology bringing about "interior transformations of consciousness" such as distance, precision, sharpened analysis and introspection. Ong (1982:101-105) argues that written words are isolated from the oral context and thus a distancing is brought about. This distancing which writing brings ".. develops a new kind of precision in verbalization by removing it from the rich but chaotic existential context of much oral utterance" (ong 1982:103-104), He (1982:104), furthermore, argues that "...written words sharpen analysis, for the individual words are called on to do more..." than spoken words which have the context of the utterance to aid their understanding or interpretation. Regarding introspection. Ong (1982:105) argues "By separating the knower from the known (Havelock 1963), writing makes possible increasingly articulate introspection..."

Third, ong (1982:117) claims that further cognitive consequences were brought about by print which "...both 
reinforces and transforms the effects of writing on thought and expression". He (1982:127) claims that one such consequence was the exact verbalisation of modern science:

Exact observation does not begin with modern science.. What is distinctive of modern science is the conjecture of exact observation and exact verbalization: exactly worded descriptions of carefuldy observed complex objects and processes. The availability of carefully made, technical prints...implemented such exactly worded descriptions.

A cognitive consequence brought about by print, according to ong. is a sense of closure which he (1982:132) defines as "... sense that what is found in a text has been finalized, has reached a state of completion". Ong (1982:132ff) argues that print encourages the idea that the thought isolated on the written surface is detached, autonomous, indifferent, uninvolved and self-contained thereby bringing about a sense of closure in analytic philosophical and scientific works.

\section{Ideological bases of literacy assumptions}

According to street (1984:1), many of the above assumptions of the 'autonomous' model are ideologically based. For instance, Hildyard and olson's claim that logical and abstract abilities are not the same for all people. They argue that we need schools to develop intellectual competence and that literacy plays a central part in its development. Street (1984:19) points out that these claims of Hildyard and olson "...thus take on the more general significance of justifying the vast expense on western education systems..." and "...already have political and ideological significance...". 
Street (1984:23) also regards Greenfield's claims, on which Hildyard and olson base their conjectures, as ideologically based:

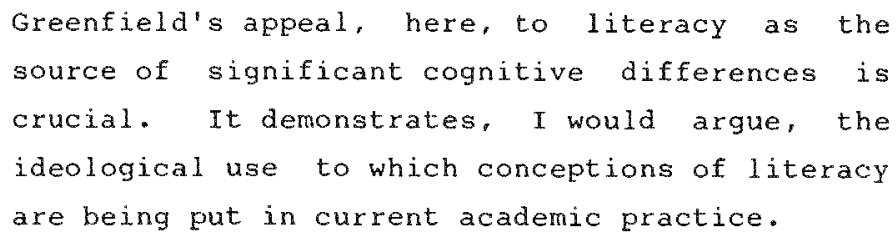

Street (1984:1) concludes that "The skills and concepts that accompany literacy acquisition, in whatever form, do not stem in some automatic way from the inherent qualities of literacy...but are aspects of a specific ideology".

5 street's "ideological" model of literacy

Street (1984:7ff) argues for his alternative model of literacy on the grounds that
A number of writers from many different disciplines and over a period of time have...expressed doubts about the grander claims made for literacy. These criticisms have not previously cohered in an explicit alternative model of the kind I describe as the 'ideological' model of literacy. However, the work produced in the last few years in this field has made it possible to begin such a process.

Street (1984:8), furthermore, proposes that work done in various disciplines has "..significant underlying premises 
in common which...provide a coherent challenge to the 'autonomous" model of literacy".

Street challenges current assumptions about literacy and claims there are implicit ideological assumptions made within what he calls the 'autonomous' model of literacy. He exposes these implicit assumptions about the cognitive consequences of literacy as false and, instead, suggests his own alternative 'ideological' model of literacy which takes into account the social contexts of literacy practices.

The 'ideological" model that street proposes regaids literacy as a social practice which is culturally and ideologically embedded. Street $(1984: 2)$ stresses the significance of the socialisation process in acquiring literacy. He $(1984: 2)$ argues that all social institutions play a role in literacy, not just the educational ones.s

I will show how each of the assumptions of the 'autonomous' model, discussed above, is refuted by street.

\subsection{An overlap of modes vs. a "great divide"}

The 'ideological' model concentrates on the overlap and interaction between the oral and literate modes of communication, rather than stressing a 'great divide" (street 1984:3). Street $(1984: 4)$ claims that all societies use a 'mix' of oral and literate modes of communication. He (1984:4) goes on to say that what is regarded as a shift from orality, to literacy is more a change in the "mix" and points out

Oral conventions often continue to apply to literate forms and literate conventions may be applied to oral forms. 
Street (1984:10) also uses work by historian Michael Clanchy (1979) to support his claim that a mix in modes of communication, rather than a 'great divide', occurs. According to clanchy, historically the shift from orality to literacy was facilitated by a mix of oral and literate modes and not by a dramatic or radical change.

Street (1984:24) challenges proponents of the "great divide" theory to take note of recent work in social anthropology, linguistics and philosophy which has discredited the 'great divide' theory.

5.2 The relation between literacy and social changes vs. literacy development in a single direction

Street (1984:10) criticises the claim that literacy development takes place in a single direction and is associated with 'progress', 'civilisation", individual liberty and social mobility by citing Graff. According to street, Graff challenges what he calls the 'literacy myth' that entails that literacy leads to social improvement, civilisation and social mobility. Graff uses the example of nineteenth century canada where the conception of literacy as neutral and autonomous was used as a form of social control rather than serving as a means of social mobility.

The social changes that literacy is associated with, are not caused by litelacy, but, rather, are aspects of specific ideologies, according to street (1984:1). Street (1984:9) also cites Gough (1968:69) to make this point. She claims that literacy is perhaps a necessary but not sufficient cause for specific social developments. 
5.3 Witeracy as socially constructed vs. literacy as a neutral technology

street $(1984: 8)$ rejects the clain that literacy is a neutral technology, arguing that literacy cannot be regarded as an autonomous thing because it "...can only be known to us in forms which already have political and ideological significance...". He (1984:2) regards Iiteracy as a social practice which is culturally and ideologically embedded. street (1984:109) cites Graff's conclusion that the meaning of literacy is context-dependent to support his claim that literacy is a social construct.

\subsection{Cognitive changes}

As we have seen above in 3.4, street criticises the assumption that literacy brings about cognitive changes.

5.4.1 Logical and abstract thought

In 3.4 .1 we have seen that, street claims that misunderstandings of meaning and ethnocentric bias underlie the assumption that literacy fosters or enforces logical and abstract thought.

\subsubsection{Scientific thought}

of the assumption that literacy fosters or enforces scientific thought, street says that evidence has shown that all societies, also non-literate ones, engage in scientific thought. (see 3.4 .2 above). 
5.5 A summary of Street's 'ideological' model

Street (1984:8) summarises the 'ideological' model as follows:

a The meaning of literacy depends on the social institutions in which it is practiced.

b Literacy cannot be regarded as an autonomous thing because it can only be known to us in forms which already have political and ideological meaning.

c Literacy is learnt in contexts which depend on social structural aspects such as stratification.

d The processes whereby literacy is learnt construct the meaning of it for particular participants.

e There are different literacies, rather than one literacy.

f Writers within the 'ideological' model "...recognise as problematic the relationship between the analysis of any 'autonomous', isolable qualities of literacy and the analysis of the ideological and political nature of literacy practice".

6. Conclusion

Street (9184:2) criticises proponents of the 'autonomous' model for failing to recognise the complexities of the many different literacy practices in different cultures. He also criticises them for privileging and generalising their own conceptions of literacy. Instead, he proposes the 
'ideological" model which, he believes, does not have these shortcomings.

of what relevance are these insights into the oralityliteracy debate to language teachers? Generally, awareness of the debate is important given a teaching situation in which it is claimed there are many students from oral backgrounds.

More specifically. Street has shown that students from oral backgrounds are capable of logical and abstract thought. Their thoughts may be expressed in unconventional ways, but axe, nevertheless, logical and abstract. The assumption language teachers can make is that students from oral backgrounds are able to deal with abstract categories like "noun" and "verb". Language teachers should not assume that these students are cognitively inferior simply because they use ungrammatical sentences. In some instances, their grammatical errors may prove to be systematic and rulegoverned and thus indicative of dialectical variation. In other instances, their errors may provide insights into the second language acquisition process.

Most importantly, in the same way that awareness of the ideological bases underlying literacy programmes will affect the planning, execution and outcome of these programmes, awareness of the ideological bases underlying language teaching will affect the planning, execution and outcome of language teaching programmes. Language teachers should ask themselves the following questions. What are their assumptions concerning students from oral backgrounds? How do these assumptions influence their choice of teaching methodology and their curriculum planning? 
NOTES

1 The assumption that literacy is a neutral technology also underlies the claim made by John Lyons that English enables its users to make neutral, objective descriptions (Street 1984:7). Street (1984:7) challenges Lyons: claim by citing the work of sociolinguists like stubbs (1980) and Rommetveit (1984) "...which challenges theories of 'autonomous' meaning. on which Lyons" arguments appear to rest, and which also challenges the 'autonomous" model of literacy".

2 According to Street (1984:20). Hildyard and Olson's central conjecture is "...that there are functions of language that are significantly affected by the mastery of a writing system, particularly its logical functions". And this entails "..that members of literate societies have the possibility of developing logical functions, of specialising in the 'truth functions' of language, and of extracting themselves from the embeddedness of everyday social life".

street (1984:27) points out that certain forms of a language may well be more explicit, but that explicitness has to do with attention to surface forms and not with $\log i c$.

4 See van Zweel (1992) for a summary of Ong's claims about the psychodynamics of orality.

5 Street (1984:2) claims that literacy is used by liberal educators to excercise social control and maintain the hegemony of the ruling class. 


\section{REFERENCES}

Clanchy, M. 1979. From membory to written record 10661307. London: E. Arnold.

Goody, J. (ed.) 1968. Literacy in traditional societies. Cambridge, London: Cambridge university press.

Goody, J. 1977. The domestication of the savage mind. Cambridge, London: Cambridge university Press.

Graff, H.J. 1979. The literacy myth: Literacy and social structure in the 19 th century city. London: Academic press.

Greenfield. P. 1972. "Oral or written language: The consequences for cognitive development in Africa, U.S. and England". Language and Speech 15.

ong. W.J. 1982. Orality and literacy. The technologizing of the word. London, New York: Methuen.

Street, B.V. 1984. Literacy in theory and practice. Cambridge, London: Cambridge university press.

van Zweel, H.A. 1992. "Factors influencing the transition from orality to literacy". SPIL PLUS 21.

stellenbosch: Department of General Linguistics. 
CONTENTS OF PREVIOUS ISSUES OF SPIL PLUS

SPIL PLUS 1 (1980)

Jeanne Maartens

Nuwe ontwikkelings binne Chomsky se teorie van kerngrammatika

SPIL PLUS 2 (1980)

Alta Oosthuizen

Leksikale basiskategorië. Probleme vir die "working grammarian"

SPIL PLUS 3 (1980)

Jeanne Maartens

Afrikaanse Sintaksis: 'n evaluering

SPIL PLUS 4 (1981)

Walter Winckler

Aspekte van die taksonomiese taalkunde

SPIL, MLUS 5 (1981)

FONOLOGIE, SEMANTIEK, TAALPOLITIEK: DRIE BESPREKINGS

R.P. Botha

Oor vrye kritiese meningswisseling en die skete van peripatete

J. Roux

Praktiese fonctick vir taalstudente ..... : 'n Evaluering

C. le Roux en M. Sinclair

'n Kritiese beskouing van Inleiding tot die Semantiek

R.H. Pheiffer

Bedenkinge oor die politieke kader van Tuiste in eie taal

SPIL PLUS 6 (1982)

REPLIEK EN KRITIEK

J.C. Steyn

Bedenklike Bedenkinge: Pheiffer se Taalpolitiek

D.P. Wissing

Fonetiek vir Eerstejaars: 'n kort waardering

\section{SPIL PLUS 7 (1982)}

CHOMSKY IN DIE JARE TAGTIG

R.P. Botha

'n Roete deur die wêreld van Chomsky

W.K. Winckler

Rules and Representations: Lees maar ... Daar staan wel wat daar staan 
SPIL PLUS 8 (1983)

TAALWETENSKAP EN DIE STUDIE VAN LITERATUUR

Rudolf P. Botha

Wat kan Taalwetenskap die student van literatuur bied?

Arnold Blumer

Basiskonsepte vir die doseer van taal en literatuur in die konseks

van 'n vreemde kultuur

Wilhelm Liebenberg

Die rol van die Taalwetenskap in die ontwikkeling van die

Literatuurwetenskap

Henning Snyman

Implikasie as taalverskynsel

Johan C. Thom en Pieter G.R. de Villiers

Die relevansie van ' $n$ linguistiese benadering tot die analise van

klassieke tekste

\section{SPIL PLUS 9 (1984)}

Hester Waher

Chomsky se teorie van 'government-binding'

SPIL PLUS 10 (1985)

\section{AFDELING I}

ALGEMENE PERSPEKTIEWE OP DIE NORMERING VAN TAALGEBRUIK

D.D. Joubert

'n Sosiologiese konsepsie van norme

J.C. Steyn

Algemene aspekte van taalnormering

V.N. Webb

$70-108$

Taainorme en Afrikaans. 'n Geval van twyfel en vertwyfeling?

W.K. Winckler

Oor die taalwetenskaplike gronde van taalgebruiksnorme:

"important" of "importantly"?

R.P. Botha en M. Sinclair

Die negende gebod in taalgebruik

AFDELING II

PERSPEKTIEWE OP DIE PRAKTYK VAN DIE NORMERING VAN AFRIKAANS

E. Raidt

Historiese perspektief op die normering van Afrikaans

L.C. Eksteen

Die rol van die Akademie in die standaardisering van die Afrikaanse spelling

D.C. Hauptfleisch

Taalnormering en woordeboeke: 'n Praktykgerigte perspektief 
T.J.R. Botha

Normering in die Afrikaanse Radio-en Televisiediens

J. Picard

Die normering van Afrikaanse vakterminologie

$292-320$

J.S. Schutte

Die taalpraktisyn as kruispunt

D.W. le Roux

Die Staatstaaldiens: Funksies en invloed ten opsigte van die normering van taalgebruik

G. Kroes

$328-344$

Die doeltreffendheid van die Afrikaanse Woordelys en Spelreëls as handleiding en naslaanbron by die onderrig van Afrikaans op tersiêre vlak

J.P. Botha

Die normering van Afrikaanse taalgebruik soos beofen in die skool en die universiteit

J.M. Marais

Taalnormering in die skool: 'n onderwyser se perspektief

J. Esterhuyse

Die dominasie yan die Afrikaner-lewensbeskouing binne die

Afrikaanse spraakgemeenskap, soos gemanifesteer in taalhandboeke vir hoërskole

L.R. Heiberg

$392-416$

Taaldokters

A. Gardiner

$417-452$

Die Afrikaanse taaldokter en die Hippokratiese eed: implikasies

vir die taalgebruiker

H. Snyman

$453-463$

Norme by literêre taalgebruik

C.J, Conradie

Die normering van Afrikaanse Bybeltaal

$464-487$

\section{AFDELING III}

PERSPEKTIEWE OP DIE NORMERING VAN ANDER TALE

E. Loubser

$489-496$

Normering op die Nederlandse taalgebied

E. Ridge

Norms in British and South African English

S. Skorge

Norme en normkritiek ten opsigte van die Duitse taal:

'n kort oorsig

P. Brink

Taalnormering in Frankryk 
J.M. Lenake \& C.F. Swanepoel

$573-590$

Historiese aspekte van normering in Suid-Sotho

A. Wilkes

Taalgebruiksnormering in die Suid-Afrikaanse Bantoetale

SPIL PLUS $11 \quad(1987)$

Rudolf P. Botha

The generative garden game: challenging Chomsky at conceptual combat

SPIL PLUS 12 (1989)

Ian B. Bedaux

The portraits of Simon van der Stel, first governor of the Cape

SPIL PLUS 13 (1989)

C. Ie Roux

On the interface of morphology and syntax

SPIL PLUS 14 (1989)

Rudolf P. Botha

The Metaphysics Market, I Merchandizing language as matter

\section{SPL PLUS 15 (1989)}

Rudolf P. Botha

The Metaphysics Market. 2 Billing language as behavioural

\section{SPIL PLUS 16 (1991)}

Hester Waher

Oor grense, kettings, en lisensies. 'n Sleutel tot Chomsky se teorie van grammatika

SPIL PLUS 17 (1991)

Rudolf $P$, Botha

The Metaphysics Market. 3 Selling language as soul

\section{SPIL PLUS 18}

M. Sinclair and W.K. Winckler

Relevance Theory. Explaining verbal communication

\section{SPIL PLUS 19 (1991)}

Rudolf $\mathrm{P}$. Botha

The Metaphysics Market. 4 Pushing language as Platonic (not to mention Popperian)

\section{SPIL PLUS 20 (1991)} social 
SPIL PLUS 21 (1992)

TAALWETENSKAP VIR DIE TAALPROFESSIES 1: DEEL A LINGUISTICS FOR THE LANGUAGE PROFESSIONS 1: PART A

R.P. Botha

Charting the anatomy of linguistic reality

Johann L. van der Walt

Linguistics and second language teaching: An assessment

Gary P. Barkhuizen

What we want from linguistics: A plea from high school

English teachers

Elizabeth de Kadt

Contrastive analysis, pragmatics and language teachers?

Vivian de Klerk

Why language teachers need linguistics

Elaine Ridge

Communicative language teaching: Time for review?

M.S. Odendaal

$109-128$

Error correction in a communicative language teaching framework

Peter Southey

129-139

Fossilization in English second language medium

$140-158$

H.W. Broekman

Circular interaction between linguistic departments and language departments

Marianna Visser

Theoretical syntax in second language acquisition research and in second language classroom research

M. Viljoen

Wat is dit wat ons met behulp van ' $n$ taaltoets evalueer?

Norah Haussmann

What exactly are we testing when we clain to be testing mothertongue communicative competence?

J. de Vynck

Taalgebruik en taalbeheersing: twee Franse modelle

J. Keith Chick.

A role for linguistics in addressing contextual issues relevant to second language teaching

Christine Anthonissen

The relevance of speech act theory for research on the acquisition of pragmatic competence by second language learners

Cecile le Roux

The problem of ethnocentric bias in speech act studies: Implications 
Kay Mc Cormick

$324-337$

Sociolinguistics and first language teaching

Jeanne Maartens

338-359

The disadvantaged non-mother-tongue speaker as university student

of Afrikaans: Possible solutions to the language lecturer's dilemma

Rosemary Granger

$360-374$

The problem of non-standard utterances used by speakers of English

as a second language at tertiary level

Margaret Inglis

The interrelationship of proficiency in a second language and understanding of scientific concepts

Ninon Roets

Insette uit die toegepaste linguistiek vir 'n kursus vir akademiese

doeleindes

E. Hilton Hubbard

Linguistics as a subversive activity: Exploding myths and

$400-410$

misconceptions in the language classroom

H. Menkveld

Die problematiek rondom die onderrig van Afrikaans (T1)

Hildegard van Zweel

Factors influencing the transition from orality to literacy

Myrtle Hooper

The rhetorics of audience consciousness: A dialogic approach to reading Donne in Zululand

Lydia McDermott

Literary analysis and exposition: The second language reader-writer

\section{SPIL PLUS 22 (1992)}

TAALWETENSKAP VIR DIE TAALPROFESSIES 1: DEEL B

LINGUISTICS FOR THE LANGUAGE PROFESSIONS 1: PART B

LITERêRE KRITIEK EN ANALISE / LITERARY CRITICISM AND ANALYSIS

Henning H.J. Snyman

$3-16$

Paradigma en parodie

Ina Gräbe

Linguistiese ondersoek en gediganalise: noodwendige verstrengeling

of marginale oorvleueling?

J.T. von Gruenewaldt

The relevance of linguistic theories in the analysis of literary texts

\section{VERTALING EN TEKSWETENSKAP / TRANSLATION AND TEXT LINGUISTICS}

Melinda Sinclair

The effects of context on utterance interpretation: Some questions and some answers 
Ferdinand Deist

Bible translation and relevance theory

Gerrie Snyman

The theologian's search for "Meaning": Restraint or liberation of the creative spirit?

C. van Schalkwyk

Vertaling - 'n diskursiewe doenigheid

G. Kroes

Die inhoud en plek van norme in die vertalpraktyk, vertaalkunde, vertaalkritiek en die vertaalwetenskap

J. du T. McLachlan

Terug na Trap der Jeugd: 'n praktykbeskouing van die resultaat van talopleiding

Anna-Marie Beukes

Die vertalberoep en taalbeplanning

Walter $\mathrm{K}$. Winckler

Missing Matthew's meaning. Or: Towards a nodding acquaintance with 'Textual Meaning' (and, maybe, with 'Context' too)

Judith A. Campbell

Semantic representation and the translation of poetry

M.E. Nelson

Perspektiewe uit die tekswetenskap op die vertaling van eiename in 'n kinderboek

Alet Kruger

Die beredeneerde betoog in die afstandonderrig van vertalers

\section{LEKSIKOGRAFIE / LEXICOGRAPHY}

Piet Swanepoel

Leksikografie en linguistiek

F.J. Lombard

Leksikograaf, woordeboekgebruiker en taalwetenskaplike:

'n kongruente of inkongruente driehoek?

John R. Taylor

How many meanings does a word have?

A.E. van Niekerk

Betekenis en gebruik in ' $n$ omvattende woordeboek

Maria Smit

Translating culture-bound words: A problem in bilingual

lexicography

Ernst F. Kotzé

Die probleem van grammatikale ekwivalensie by ' $n$ vertalende aanleerderswoordeboek 
Klaus Menck

Die woordeboek as hulp middel - en nie as struikelblok - in

vreemdetaalonderrig

\section{SPRAAKTERAPIE / SPEECH THERAPY}

E. Alant

$407-416$

Die tersaaklikheid van taalwetenskap vir spraakheelkunde

Jenny Pahl

Speech-language therapy with Zulu clients: Implications for linguistics

\section{INLIGTINGKUNDE / INFORMATION SCIENCE}

L.G. de Stadler and M.W. Coetzer

A morphological parser for Afrikaans

\section{TAALBEPLANNING / LANGUAGE PLANNING}

C.S. Johl

Die relevansie van linguistiek en literatuurwetenskap in 'n post-apartheidgemeenskap

\section{David Brown}

Sociolinguistic practice and political change: Critical appraisal of the language atlas of South Africa

\section{Walter McKay}

Marginal limitations: Report from a vanishing empire

V. Prabhakaran

The political situation as a factor in shift and maintenance of the Telugu language in South Africa

\section{SPIL PLUS 23 (1994)}

Paul T. Roberge

The formation of Afrikaans

\section{SPIL PLUS 24 (1994)}

Rudolf P. Botha

The World of Language: 1 Its crust

\section{SPIL PLUS 25 (1994)}

Rudolf P. Botha

The World of Language: 2 Its behavioural belt 